\title{
Inflammatory response and the endothelium
}

\author{
P.L. Meroni ${ }^{a, *}$, M.O. Borghi ${ }^{a}$, E. Raschi ${ }^{a}$, D. Ventura ${ }^{a}$, P.C. Sarzi Puttini ${ }^{b}$,

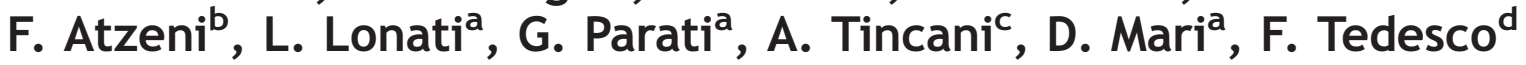

\author{
a Department of Internal Medicine, University of Milan, Istituto Auxologico Italiano, Italy \\ ${ }^{\mathrm{b}}$ Rheumatology Division, Ospedale L Sacco, Milan, Italy \\ 'Spedali Civili, Brescia, Italy \\ 'University of Trieste, Italy
}

Received 1 June 2004; received in revised form 21 June 2004; accepted 23 June 2004

Available online 7 August 2004

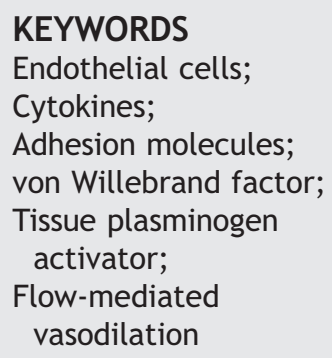

\begin{abstract}
Antiphospholipid-mediated endothelium perturbation plays a role in antiphospholipid syndrome (APS)-associated vasculopathy. Antiphospholipid antibodies activate endothelium both in vitro and in vivo experimental models by inducing a pro-inflammatory/-coagulant phenotype; the antibodies recognize $\beta 2$ glycoprotein I $(\beta 2 \mathrm{GPI})$ on human endothelial cells $(\mathrm{EC})$ from different parts of the vasculature.

In spite of such large in vitro evidence, few studies have addressed the issue whether or not a comparable endothelial perturbation might be detectable in vivo.

We investigated several indirect ex vivo parameters of endothelial dysfunction: plasma levels of soluble adhesion molecules (SADM), soluble thrombomodulin (STM), von Willebrand factor (vWF) and tissue plasminogen activator (t-PA) by solid-phase assays. The study included: patients with primary antiphospholipid syndrome $(n=32)$, with the syndrome secondary to non-active systemic lupus erythematosus (SLE, $n=10$ ), six patients with persistent antiphospholipid positivity at medium/high titre without any clinical manifestation of the syndrome. Fifty-two age and sex matched healthy subjects have been enrolled as controls. In addition, circulating endothelial cells identified by flow cytometry and the brachial artery flow-mediated vasodilation (FMV) were evaluated in 26 patients ( 20 primary and 6 lupus syndromes) and 30 healthy controls.
\end{abstract}

Abbreviations: aPL, anti-phospholipid antibody; EC, endothelial cell; LA, lupus anticoagulant; PGI 2 , prostacyclin; TXA thromboxane; APS, antiphospholipid syndrome; $\beta 2 \mathrm{GP}, \beta 2$ glycoprotein I; sADM, soluble adhesion molecules; LPS, lipopolysaccharide; TF, tissue factor; HUVEC, human umbilical cord vein endothelial cells; HS, heparan sulphate; t-PA, tissue plasminogen activator; IL, interleukin; TNF, tumor necrosis factor;TLR, Toll-like receptor; sTM, soluble thrombomodulin; vWF, von Willebrand; SLE, systemic lupus erythematosus; FMV, flow-mediated vasodilation; ANCA, anti-neutrophil cytoplasmic antibody.

* Corresponding author. Allergy, Clinical Immunology and Rheumatology Unit, IRCCS Istituto Auxologico Italiano, Via Spagnoletto, 3 , 20149 Milan, Italy. Fax: +39 2619112559.

E-mail address: pierluigi.meroni@unimi.it (P.L. Meroni). 
Plasma levels of soluble adhesion molecules did not differ from controls, while a significant increase in von Willebrand factor titres $(P<0.05)$ was found. No significant difference was found regarding the number of circulating endothelial cells and flow-mediated vasodilation.

As a whole, these findings do suggest that antiphospholipid antibodies per se are not able to support a full-blown endothelial perturbation in vivo. As shown in antiphospholipid syndrome experimental animal models, a two-hit hypothesis is suggested.

(C) 2004 Elsevier Ltd. All rights reserved.

The ability of anti-phospholipid antibody (aPL) to interact with endothelial cells (EC) was initially suggested by Carreras and Vermylen [1]. They demonstrated that lupus anticoagulant (LA) positive plasmas can suppress prostacyclin $\left(\mathrm{PGI}_{2}\right)$ release by vascular endothelium and in turn affect the balance between endothelial $\mathrm{PGI}_{2}$ and platelet thromboxane $\left(\mathrm{TXA}_{2}\right)$ favouring an antiphospholipid syndrome (APS) hypercoagulable state.

More recently, aPL IgG fractions were shown to up-regulate endothelial expression of adhesion molecules (ADM) and leukocyte adherence in vitro [2]. At the same time, our group demonstrated that such an activity was related to the anti- $\beta 2$ glycoprotein I ( $32 \mathrm{GPI})$ antibody specificity $[3,4]$. These findings confirmed and extended the observation that anti-cardiolipin IgG fractions activated EC in the presence of $\beta 2 \mathrm{GPI}[2]$. Following these studies, other groups have confirmed this finding by using both polyclonal and monoclonal aPL [5-8]. Interestingly, aPL-mediated activation with ADM upregulation and pro-inflammatory cytokine secretion was also found with human brain and skin primary EC cultures, suggesting that such an effect might be generalized to EC from different anatomical sites [9].

It is important to point out that EC activation has been reproduced in an in vivo experimental animal APS model by Pierangeli at al. [7]. We recently described an additional experimental in vivo model, in which the infusion of IgG fractions with strong anti- $\beta 2 \mathrm{GPI}$ activity but not control IgG can induce leukoaggregation in the mesenteric rat microcirculation when small amounts of lipopolysaccharide (LPS) are also injected at the same time (Fischetti et al., 2004, personal communication).

\section{The pleiotropic aPL effect on endothelial cells}

Several in vitro studies have shown that incubation of EC with aPL can generate different effects on endothelial function.
In fact, besides the interference with the eicosanoid metabolism and the induction of a proadhesive phenotype, in vitro EC incubation with aPL was reported to be able: (i) to up-regulate proinflammatory and chemokine synthesis and secretion [5-8], (ii) to modulate tissue factor (TF) expression on the cell membrane $[10,11]$, (iii) to interfere with the protein C/S activation (review in Ref. [12]), (iv) to displace annexin $\mathrm{V}$ binding to the cell membrane [13], (v) to induce pre-pro-endothelin (ET)-I synthesis [14], (vi) to favour an apoptotic process $[15,16]$ and (vii) to interact with late endosomes [17] (Table 1).

As a whole, these effects might cooperate in sustaining the endothelial perturbation that has been suggested to play a pivotal pathogenic role in APS-associated thrombophilic state.

\section{$\beta 2 \mathrm{GPI}$ as the main endothelial target antigen for aPL}

The demonstration that APS sera might recognize antigenic determinants on EC membrane is the necessary requisite to explain any interaction between $\mathrm{aPL}$ and EC. By using an immunoprecipitation assay that specifically radiolabelled HUVEC apical cell surface proteins, two groups independently reported that APS sera immunoprecipitated several EC membrane proteins with a molecular weight ranging from 200 to $24 \mathrm{kDa}[18,19]$. Additional studies demonstrated that most of the endothelial binding of aPL positive IgG fractions was closely related to the anti- $\beta 2 \mathrm{GPI}$ activity (review in Ref. [12]). Moreover, affinity purified

Table 1 Pleiotropic effect of aPL on endothelial cells

- Induction of a pro-inflammatory phenotype

- Tissue factor up-regulation

- Interaction with the protein $\mathrm{C} / \mathrm{S}$ system

- Interaction with annexin V

- Interaction with the eicosanoid metabolism

- Induction of pre-proET-1 synthesis

- Induction of apoptosis

- Interaction with the late endosomes 
polyclonal IgG or human monoclonal IgM with anti32GPI specificity were found to recognize the molecule on the EC surface membrane (review in Ref. [12]).

Plasma proteins can adhere to EC and the presence of $\beta 2 \mathrm{GPI}$ on the endothelium was suggested to be, at least in part, due to such a general phenomenon [20]. Actually, extensive washing and culture in serum-free medium abolished the anti$\beta 2 \mathrm{GPI}$ reactivity with human umbilical cord vein endothelial cell (HUVEC) monolayers that was in turn restored by the addition of purified $32 \mathrm{GPI}$ (review in Ref. [12]). Interestingly, such a phenomenon was found with HUVEC monolayers but not with primary human EC cultures from skin or brain micro-circulation [9]. It has been suggested that EC might synthesize $\beta 2 \mathrm{GPI}$ themselves, but this has not been substantiated (review in Ref. [12]).

Our own group demonstrated that $\beta 2 \mathrm{GPI}$ binds to EC membranes through the putative PL-binding site-a highly positively charged amino acid sequence, located in the fifth domain of $\beta 2 \mathrm{GPI}$ and previously shown to be involved in the binding to cardiolipin-coated plates (review in Ref. [12]). It has been suggested that heparan sulphate (HS)-the major proteoglycan of the vascular endothelium that constitutes the majority of the constitutive endothelial anionic sites (review in Ref. [12])might be the corresponding negatively charged structure for the $32 \mathrm{GPI}$ PL-binding site. In agreement with such a hypothesis, HUVEC treatment with heparitinase I, an enzyme able to cleave specifically the $\alpha-N$-acetyl-D-glycosaminidic linkage in HS, significantly down-regulates $\beta 2 \mathrm{GPI}$ binding [9]. However, even the highest enzyme concentrations gave an inhibition only up to $65 \%$. Although these findings indicate that HS is involved in $\beta 2 \mathrm{GPI}$ binding, endothelial structures other than $\mathrm{HS}$ should be considered to bind $\beta 2 \mathrm{GPI}$.

Megalin-an endocytic receptor expressed on placenta, kidney and other tissues-was reported as a possible receptor for $\beta 2 \mathrm{GPI}$ [21]. However, Cao et al. [22] showed that megalin-mRNA was not expressed in both human vein and arterial umbilical EC. Moreover, $\beta 2 \mathrm{GPI}$ binding to megalin was reported to be $\mathrm{Ca}^{2+}$ ion-dependent; however, it is not affected at all when HUVEC are cultured in EDTA buffer (Meroni et al., personal communication). Altogether, these data are consistent with the fact that megalin is not likely involved in EC $\beta 2 \mathrm{GPI}$ binding.

More recently, $\beta 2 \mathrm{GPI}$-binding proteins of $\sim 70$ and $\sim 36 \mathrm{kDa}$ from HUVEC and EAhy. 926 cells were found to be identical in amino acid sequence to annexin II [23], an endothelial receptor for tissue plasminogen activator (t-PA) [24-26]. In addition, radio- labelled $\beta 2$ GPI was found to adhere at high affinity to Annexin II-transfected HEK 293 cells and the adhesion to HUVEC was inhibited by anti-annexin II antibodies [23]. The authors suggested that Annexin II might represent an EC membrane receptor for $\beta 2 \mathrm{GPI}$.

Whatever the endothelial receptor for $\beta 2 \mathrm{GPI}$ is, all the reported findings do support the hypothesis that adhered $\beta 2 \mathrm{GPI}$ offers suitable epitopes for anti- $\beta 2$ GPI antibodies either by making available high density immunogenic epitopes or by displaying new cryptic epitopes comparable to those detectable on ELISA plates either coated with anionic phospholipids or $\gamma$-irradiated.

\section{Endothelial activation by aPL}

We and others have demonstrated that anti- $32 \mathrm{GPI} /$ aPL antibodies were able to induce a pro-inflammatory and a pro-adhesive endothelial phenotype through NF-kB activation in a similar way to that found with standard agonists such as IL-1 $\beta$, TNF- $\alpha$ and LPS (review in Refs. [12,10]).

The NF-kB upstream EC activation pathways have been recently investigated and reported to be mediated by TRAF adapter family. TRAF-2 plays a critical role in the presence of TNF- $\alpha$; TRAF- 6 is employed in IL-1 and LPS signalling pathways [27] and the MyD88 is identified as a further mediator molecule involved in the IL-1/LPS activation cascade. By using EC transfected with negative dominants of TRAF-2/-6 or MyD88 our group indicated that both human monoclonal IgM as well as polyclonal lgG with anti- $32 \mathrm{GPI}$ activity induced a signalling cascade comparable to that activated by LPS or IL-1 [28]. Additional studies on the phosphorylation time kinetic of the IRAK-the first kinase to be recruited by the IL-1/Toll-like receptor (TLR) superfamily-suggested that the autoantibodies activated EC through the TLR-4 involved in LPS pathway [28].

TLR are key components of the innate immune response able to recognize specific microbial products, including LPS, bacterial lipoproteins, peptidoglycan and bacterial DNA [29]. TLR expression is a widespread phenomenon in both lymphoid and non-lymphoid tissues; in particular, TLR-4 is found on EC, monocytes, neutrophils and dendritic cells [29].

The relationship between TLRs and $\beta 2 \mathrm{GPI}$ is apparently supported by the molecular mimicry shared by $\beta 2 \mathrm{GPI}$ and different microbial pathogens-the natural ligands of TLRs $[29,30,31,32,33]$. We speculate that $\beta 2 \mathrm{GPI}$ might adhere to EC through its PL-binding site and membrane anionic structures 
and to interact with TLRs because of such a homology. In turn, anti- $\beta 2 \mathrm{GPI}$ antibodies might cross-link the complex eventually triggering the inflammatory response through the TLR cascade.

As stated before, $\beta 2 \mathrm{GPI}$ can also bind annexin II. However, it has been reported that annexin II does not span the cell membrane, so the interaction between $\beta 2 \mathrm{GPI}$ linked to annexin II and anti- $\beta 2 \mathrm{GPI}$ antibodies would not be sufficient to induce any intra-cytoplasmic signal and probably does require a yet unknown "adaptor" protein [23-26]. We speculate that $\beta 2 \mathrm{GPI}$ behaves as a "bridge" between annexin II and TLR-4 on EC and at the same time it might offer suitable antigenic epitopes for the circulating autoantibodies. Antibody reactivity with such a complex could eventually cluster the right membrane molecules and trigger the cell signalling (Fig. 1).

\section{Do aPL induce an endothelial perturbation in vivo too?}

There is evidence that $\beta 2 \mathrm{GPI}$ can be expressed also on EC in vivo. Antisera specific for human $\beta 2 \mathrm{GPI}$ give a clear staining on trophoblast vessels in term placentas $[34,35]$. However, in spite of the in vitro data with human primary skin EC cultures, we did not find a comparable endothelial staining in skin biopsies obtained from normal donors or patients

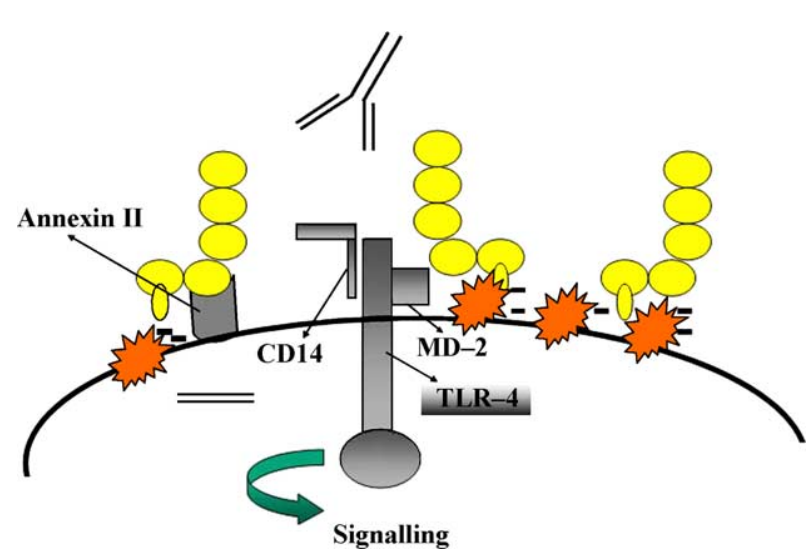

Figure 1 Possible mechanisms for $\beta 2 \mathrm{GPI}$ binding to endothelial cell membrane and cell signalling. Beta2GPI can bind to endothelial cell membrane via the electric charge interactions between the cationic phospholipid binding site and anionic structures or as a ligand for specific receptors (annexin II). The molecule can also interact with the adjacent TLR because of its homology with the microbial ligands for TLRs. Cell signalling might take place once circulating anti- $\beta 2 \mathrm{GPI}$ antibodies recognize the adhered molecules and cluster the complexes. affected by inflammatory disorders (unpublished observations).

The question whether an endothelial perturbation comparable to that detectable in in vitro studies might be also detectable in vivo in APS patients has been addressed by few studies. Different indirect parameters of EC perturbation ex-vivo have been investigated with no definite conclusions. While some studies reported increased plasma levels of single soluble ADM or endothelial derived microparticles in APS patients, others did not confirm these findings [36-39]. Additional confounding variables-such as a concomitant associated immune-mediated systemic inflammatory disorder-did weaken the comparison. These findings are in contrast to those that demonstrate the aPL thrombogenic effect is closely mediated by ADM expression in a murine experimental model [40]. On the other hand, clear histological signs of endothelial activation have been reported only in biopsies taken from patients affected by the APSrelated heart valvulopathy [41].

We investigated several indirect in vivo parameters of endothelial dysfunction in aPL positive patients: SADM: (sEselectin, sICAM-1, sVCAM-1), STM, VWF and t-PA evaluated by solid-phase assays. Plasma levels of soluble ADM, as well as levels of sTM, vWF and t-PA have been reported to be increased in different disorders characterized by the presence of an endothelial perturbation $[42,43]$. These parameters have been investigated in: 32 patients with primary APS, 10 with APS secondary to systemic lupus erythematosus (SLE) and 4 SLE patients. All the included SLE patients displayed non-active disease (ECLAM score $\leq 2$ ) in order to avoid any potential variables related to the immune-mediated inflammation sustained by the lupus disease itself. Additional two patients with persistent antiphospholipid positivity at medium/high titre but without any clinical manifestations and 52 age- and sex-matched controls were studied.

In addition a series of patients (20 primary and 6 SLE APS) was investigated for: (i) the presence of circulating EC identified by flow cytometry and (ii) the brachial artery flow-mediated vasodilation (FMV) at rest, during reactive hyperemia and after glyceryl nitrate. High levels of circulating EC have been reported in patients suffering from disorders characterized by an endothelial damage sustained by systemic immune-mediated inflammation such as in patients suffering from anti-neutrophil cytoplasmic antibody (ANCA)-associated vasculitis or by ischaemic processes [44]. An impaired endothelialdependent FMV has been also reported in comparable conditions [45]. 
Plasma levels of soluble ADMs and STM did not reach a statistical significance in APS patients in comparison with controls; t-PA levels showed an increase in patients that however did not reach the statistical significance. On the contrary, significantly increased vWF titres were found in APS patients. No significant difference between patients and controls was found regarding the number of circulating EC as well as the brachial artery FMV.

As a whole, these findings do support that aPL per se are not able to induce significant endothelial perturbation in vivo. This finding is in line with the results reported in the experimental animal models in which the infusion of aPL does not trigger clot formation or a strong endothelial activation in uninjured vessels unless a mechanical trauma or an inflammatory trigger is applied (Fischetti et al., 7, 2004, submitted). In this regard, a two-hit hypothesis has been suggested: aPL (first hit) increases the risk of thrombotic events by inducing a threshold endothelial perturbation; however, another thrombophilic condition (second hit) is required in order to trigger the clot formation. Moreover, the two hit hypothesis might also explain why patients persistently positive for aPL do display thrombotic events only occasionally.

\section{Aknowledgments}

The paper has been supported by Ricerca Corrente Istituto Auxologico Italiano 2003-04 (to PLM).

\section{References}

[1] Carreras LO, Vermylen JG. Lupus anticoagulant and thrombosis: possible role of inhibition of prostacyclin formation. Thromb Haemost 1982;48:38 - 40.

[2] Simantov R, La Sala JM, Lo SK, Gharavi AE, Sammaritano LR, Salmon JE, et al. Activation of cultured vascular endothelial cells by antiphospholipid antibodies. J Clin Invest 1995; $96: 2211-9$.

[3] Del Papa N, Guidali L, Spatola L, Bonara P, Borghi MO, Tincani A, et al. Relationship between anti-phospholipid and anti-endothelial antibodies III: $\beta 2$-glycoprotein I mediates the antibody binding to endothelial membranes and induces the expression of adhesion molecules. Clin Exp Rheumatol 1995;13:179-86.

[4] Del Papa N, Guidali L, Sala A, Buccellati C, Khamashta MA, Ichikawa K, et al. Endothelial cell as target for antiphospholipid antibodies. Arthritis Rheum 1997;40:551-61.

[5] Dueymes M, Piette JC, Le Tonqueze M, Bendaoud B, Roue R, Garre $M$, et al. Role of $\beta 2$-glycoprotein I in the anti- phospholipid antibody binding to endothelial cells. Lupus 1995;4:179-86.

[6] George J, Blank M, Levy Y, Meroni P, Damianovich M, Tincani A, et al. Differential effects of anti-beta 2 glycoprotein antibodies on endothelial cells and on the manifestations of experimental antiphospholipid syndrome. Circulation 1998; 97:900-6.

[7] Pierangeli SS, Colden-Stanfield M, Liu X, Barker JH, Anderson GL, Harris EN. Antiphospholipid antibodies from antiphospholipid syndrome patients activate endothelial cells in vitro and in vivo. Circulation 1999;99:1997-2002.

[8] Cho CS, Cho ML, Chen PP, Min SY, Hwang SY, Park KS, et al. Antiphospholipid antibodies induce monocyte chemoattractant protein-1 in endothelial cells. J Immunol 2002;168: $4209-4215$.

[9] Meroni PL, Tincani A, Sepp N, Raschi E, Testoni C, Corsini E, et al. Endothelium and the brain in CNS lupus. Lupus 2003; 12:919-28.

[10] Dunoyer-Geindre S, de Moerloose P, Galve-de Rochemonteix B, Reber G, Kruithof EK. NFkappaB is an essential intermediate in the activation of endothelial cells by antibeta(2)-glycoprotein 1 antibodies. Thromb Haemost 2002; 88:851-7.

[11] Branch DW, Rodgers GM. Induction of endothelial cell tissue factor activity by sera from patients with antiphospholipid syndrome: a possible mechanism of thrombosis. Am $J$ Obstet Gynecol 1993;168:206-10.

[12] Meroni PL, Raschi E, Testoni C, Tincani A, Balestrieri G. Antiphospholipid antibodies and the endothelium. Rheum Dis Clin North Am 2001;27:587-602.

[13] Rand JH. Molecular pathogenesis of the antiphospholipid syndrome. Circ Res 2002;90:29-37.

[14] Atsumi T, Khamashta MA, Haworth RS, Brooks G, Amengual $\mathrm{O}$, Ichikawa $\mathrm{K}$, et al. Arterial disease and thrombosis in the antiphospholipid syndrome: a pathogenic role for endothelin 1. Arthritis Rheum 1998;41:800-7.

[15] Nakamura N, Shidara Y, Kawaguchi N, Azuma C, Mitsuda N, Onishi $\mathrm{S}$, et al. Lupus anticoagulant autoantibody induces apoptosis in HUVEC: involvement of annexin V. Biochem Biophys Res Commun 1994;205:1488-93.

[16] Bordron A, Dueymes M, Levy Y, Jamin C, Ziporen L, Piette $\mathrm{JC}$, et al. Anti-endothelial cell antibody binding makes negatively charged phospholipids accessible to antiphospholipid antibodies. Arthritis Rheum 1998;41:1738-47.

[17] Dunoyer-Geindre S, de Moerloose P, Galve-de Rochemonteix B, Reber G, Kruithof EK. Interaction of anti-phospholipid antibodies with late endosomes of human endothelial cells. Arterioscler Thromb Vasc Biol 2000;20:563-74.

[18] Zhang JC, Sakthivel R, Kniss D, Graham CH, Strickland DK, McCrae KR. Detection of endothelial cell reactive immunoglobulin in patients with anti-phospholipid antibodies. $\mathrm{Br} \mathrm{J}$ Haematol 1991;79:595-605.

[19] Del Papa N, Conforti G, Gambini D, La Rosa L, Tincani A, D'Cruz D, et al. Characterization of the endothelial surface proteins recognized by anti-endothelial antibodies in primary and secondary autoimmune vasculitis. Clin Immunol Immunopathol 1994;70:211-6.

[20] Revelen R, Bordron A, Dueymes M, Youinou P, Arvieux J. False positivity in a cyto-ELISA for anti-endothelial cell antibodies caused by heterophile antibodies to bovine serum proteins. Clin Chem 2000;46:273-8.

[21] Moestrup SK, Schousboe I, Jacobsen C, Leheste JR, Christensen El, Willnow TE. $32-$-Glycoprotein-I (apolipoprotein $\mathrm{H}$ ) and $\beta 2$-glycoprotein-I-phospholipid complex harbor a recognition site for the endocytic receptor megalin. $J$ Clin Invest 1998;102:902-9. 
[22] Cao W, Atsumi T, Yamashita Y. A possible binding of $\beta 2$ glycoprotein I to megaline, an endocytic receptor on trophoblast. J Autoimmun 2000;A61.

[23] Ma K, Simantov R, Zhang JC, Silverstein R, Hajjar KA, McCrae KR. High affinity binding of $\beta 2$-glycoprotein I to human endothelial cells is mediated by annexin II. J Biol Chem 2000;20:15541-8.

[24] Hajjar KA, Jacovina AT, Chacko J. An endothelial cell receptor for plasminogen/tissue plasminogen activator: I. Identity with annexin II. J Biol Chem 1994;269:21191-7.

[25] Hajjar KA, Mauri L, Jacovina AT, Zhong F, Mirza UA, Padovan $\mathrm{JC}$, et al. Tissue plasminogen activator binding to the annexin II tail domain. Direct modulation by homocysteine. J Biol Chem 1998;273:9987-93.

[26] Cesarman GM, Guevara CA, Hajjar KA. An endothelial cell receptor for plasminogen/tissue plasminogen activator (t-PA): II. Annexin II-mediated enhancement of t-PAdependent plasminogen activation. J Biol Chem 1994; 269:21198-203.

[27] Muzio M, Natoli G, Saccani S, Levrero M, Mantovani A. The human toll signaling pathway: divergence of nuclear factor $\mathrm{kB}$ and JNK/SAPK activation upstream of tumor necrosis factor receptor-associated factor 6 (TRAF6). J Exp Med 1998; 187:2097-101.

[28] Raschi E, Testoni C, Bosisio D, Borghi MO, Koike T, Mantovani A, et al. Role of the MyD88 transduction signaling pathway in endothelial activation by anti-phospholipid antibodies. Blood 2003;101:3495-500.

[29] Medzhitov R. Toll-like receptors and innate immunity. Nat Rev, Immunol 2001;1:135-45.

[30] Gharavi AE, Pierangeli SS, Colden-Stanfield M, Liu XW, Espinola RG, Harris EN. GDKV-induced antiphospholipid antibodies enhance thrombosis and activate endothelial cells in vivo and in vitro. J Immunol 1999;163:2922-7.

[31] Gharavi AE, Pierangeli SS, Espinola RG, Liu XW, ColdenStanfield M, Harris EN. Antiphospholipid antibodies induced in mice by immunization with cytomegalovirus-derived peptide cause thrombosis and activation of endothelial cells in vivo. Arthritis Rheum 2002;46:545-52.

[32] Blank M, Krause I, Fridkin M, Keller N, Kopolovic J, Goldberg I, et al. Bacterial induction of autoantibodies to $\beta 2$-glycoprotein-1 accounts for the infectious etiology of antiphospholipid syndrome. J Clin Invest 2002;109: $797-804$

[33] Shoenfeld Y. Etiology and pathogenetic mechanisms of the anti-phospholipid syndrome unraveled. Trends Immunol 2003;24:2-4.
[34] McIntyre JA. Immune recognition at the maternal-fetal interface: overview. Am J Reprod Immunol 1992;28: $127-131$

[35] La Rosa L, Meroni PL, Tincani A, Balestrieri G, Faden D, Lojacono A, et al. $\beta 2$-Glycoprotein I and placental anticoagulant protein I in placentae from patients with antiphospholipid syndrome. J Rheumatol 1994;21:1684-98.

[36] Combes V, Simon AC, Grau GE, Arnoux D, Camoin L, Sabatier $\mathrm{F}$, et al. In vitro generation of endothelial microparticles and possible prothrombotic activity in patients with lupus anticoagulant. J Clin Invest 1999;104:93-102.

[37] Kaplanski G, Cacoub P, Farnarier C, Marin V, Gregoire R, Gatel $\mathrm{A}$, et al. Increased soluble vascular cell adhesion molecule 1 concentrations in patients with primary or systemic lupus erythematosus-related antiphospholipid syndrome: correlations with the severity of thrombosis. Arthritis Rheum 2000;43:55-64.

[38] Frijns CJ, Derksen RH, De Groot PG, Algra A, Fijnheer R. Lupus anticoagulant and history of thrombosis are not associated with persistent endothelial cell activation in systemic lupus erythematosus. Clin Exp Immunol 2001; 125:149-54.

[39] Williams FM, Parmar K, Hughes GR, Hunt BJ. Systemic endothelial cell markers in primary antiphospholipid syndrome. Thromb Haemost 2000;84:742-6.

[40] Pierangeli SS, Espinola RG, Liu X, Harris EN. Thrombogenic effects of antiphospholipid antibodies are mediated by intercellular cell adhesion molecule-1, vascular cell adhesion molecule-1, and P-selectin. Circ Res 2001;88:245-50.

[41] Erkan D, Roman MJ, Tenedios F, Lockshin MD. Cardiac involvement in the antiphospholipid syndrome. In: Doria A, Pauletto $\mathrm{P}$, editors. Heart in systemic autoimmune diseases. Amsterdam: Elsevier; 2004. p. 213-26.

[42] Raitakari OT, Celermajer DS. Testing for endothelial dysfunction. Ann Med 2000;32:293-304.

[43] Boffa MC, Karmochkine M. Thrombomodulin: an overview and potential implications in vascular disorders. Lupus 1998; 7:S120.

[44] Dignat-Gorge F, Sampol J. Circulating endothelial cells in vascular disorders: new insights into an old concept. Eur J Haematol 2000;65:215-20.

[45] Faulx MD, Wright AT, Hoit BD. Detection of endothelial dysfunction with brachial artery ultrasound scanning. Am Heart J 2003;145:943-51. 